Article

\title{
Tourism Family-Business Owners' Risk Perception: Its Impact on Destination Development
}

\author{
Gundula Glowka *(D) and Anita Zehrer \\ Family Business Center, Management Center Innsbruck, Innsbruck 6020, Austria; Anita.Zehrer@mci.edu \\ * Correspondence: Gundula.Glowka@mci.edu
}

Received: 15 October 2019; Accepted: 4 December 2019; Published: 7 December 2019

check for updates

\begin{abstract}
In developing and sustaining tourism, destination management involves the coordination of various stakeholders, and theory suggests that securing sustainability, including stakeholder interests in decision-making and strategic planning is crucial. Therefore, understanding stakeholders' interests and relationships is also essential. In the Austrian Alpine region, small- and medium-sized family businesses offering tourism products dominate the rural tourism landscape. However, little research has been done on how these family firms contribute to shaping the destination's future. Therefore, through guided interviews, this qualitative study examined family-business owners' perceptions of risks for Austrian tourism destination development. Family firms externalized such risks as labor shortage as a structural issue and neglected their responsibility to attract employees by improving working conditions. Thus, the externalization of risks to other stakeholder groups prevented family firms' proactive approach to sustainable destination development.
\end{abstract}

Keywords: family business; stakeholder; destination development; risk perception

\section{Introduction}

To be sustainable and to remain competitive in the long run, every tourism destination must manage risk given its specific characteristics and environment. This implies that actors must first perceive these risks [1] and second that, if necessary, someone must take the responsibility to act. So far, the Tirol's tourism has been very successful, making it an interesting example to investigate, even more so because risks like climate change may endanger its future sustainability.

In the Tirol's Alpine areas, tourism contributes much to economic development. Accounting for approximately 50 million overnight stays in 2018, one-third of Austria's tourism is based in the Tirol [2] because of its magnificent mountain landscapes and some of the world's best skiing. These circumstances have implications for tourism destinations' organization, in that "nature-based industries like rural tourism are dominated by family firms" [3] (p. 1204). The county offers 355,000 beds and 22,055 accommodation providers [4], but most are small- and medium-sized family firms operating rural tourism and thus follow the logic of a community destination model [5,6]. Rural family firms typically depend on their surrounding natural environment and aim to conserve and develop their region's natural heritage [7]. Within community destinations, businesses are independent units operated by entrepreneurs, and no unit wields dominant administrative power within the destination $[6,8]$. Tirol's tourism destinations are divided into 34 districts, each with a destination management organization (DMO) [9]. One of them, Pillerseetal, is located in the Kitzbühler Alpen, adjacent to the German border [4]. Annually, the destination accounts for one million overnight stays [9]. Following the reform of destination management at the county level, the five Pillerseetal areas merged in 2002 [10]. Today, the DMO defines each of the five areas as an adventure destination space. Thus, the DMO does not perceive itself as a strong brand, but rather as an experience area, and various communities position themselves differently. A member of the Freeride World Tour, Fieberbrunn is the main skiing area, 
specializing in free riding [11]. Hochfilzen focuses on biathlons, while St. Jakob in Haus and St. Ulrich am Pillersee offer relaxation, climbing, or husky racing. Waidring is connected to the Steinplatte skiing area and, in summer, is known for climbing [12].

Within the past decade, tourism research has addressed sustainability as a major topic for tourism planning and development $[13,14]$. As mentioned previously, to remain sustainable, a tourism destination faces a number of risks that must be managed to remain competitive in the long run $[15,16]$. One key factor in a sustainable development approach is including such stakeholders as the present and future host community [14], since various stakeholders contribute to a region's tourism development [17]. In the recent past, the stakeholder theory has been used to argue for including all relevant stakeholders to secure long-term success [18]. According to the stakeholder theory, an organization should direct its strategy toward satisfying its stakeholders' needs [19] and thus remain sustainable over time [20]. In managing all stakeholders, understanding stakeholder groups' differing interests and relationships is essential [21]. As a result, stakeholder management emphasizes shared interests and relationships, while including the business environment [22].

However, gaps still exist in understanding relationships among various stakeholders and their interests' interactions. In this study, one stakeholder group, namely family-business owners in the Pillerseetal district's rural accommodation sector, are the research object. To evaluate family-business owners' contribution to destination sustainability, this study investigates how they perceive risks and, more importantly, how they perceive their scope of action. This qualitative study's aim is thus to analyze how family tourism businesses perceive their responsibility for addressing risk within their scope of action and how risk management is sometimes externalized to another destination stakeholder. Thus, data were analyzed to understand how family firms see their scope of action with regard to externalization of effects versus action taken within their own businesses. Insight into DMO stakeholder relationships and individual family firm owners are provided to contribute to better understanding of stakeholder views and relationships at tourism destinations. Therefore, this research might contribute to improved management of sustainable tourism development, once stakeholder groups' scope of action is considered.

Family firms can be diverse in size and structure [23], but Tirol has mainly small- and medium-sized businesses (with no more than 250 employees) that are the object of this research. In investigating the Pillerseetal, one homogenous group of family firms is examined. In general, self-perception as a family-run business is regarded as essential for classification as a family business [24]. Moreover, this study defines a family business as one owning more than $50 \%$ of the firm with at least two family members working in it [25].

Next, the literature review on sustainable tourism development, stakeholder theory, and family firms is presented. Then, a section on method presents this study's qualitative approach. For the results, four perceived main risks are described in detail to show family businesses' perception of addressing risks. The discussion attempts to connect family firms' risk perception to impact on sustainable tourism development. Before concluding, the article outlines the research's limitations and implications.

\section{Literature Review}

\subsection{Stakeholder Theory and Its Application to Sustainable Tourism Development}

Historically, the stakeholder theory developed as an approach for addressing environmental changes and turbulence over the long run [26], and its aim was to facilitate management practices that capture multiple relationships among numerous groups influencing a firm's strategic choices [20]. Hence, stakeholders are any group that can influence or be influenced by the organization's objectives [27]. A firm's vision and goals should therefore incorporate the needs of its stakeholder groups, thus enabling them to identify with the firm and, as a result, secure the firm's sustainability. Businesses follow a stakeholder approach to create value for all stakeholders from a long-term 
perspective [28]. This means the firm's business management needs to understand relationships among stakeholders [26].

The stakeholder theory has descriptive, instrumental, and normative aspects [27]. It describes an organization "as a constellation of cooperative and competitive interests possessing intrinsic value" [27]. It is instrumental, providing a framework linking "the practice of stakeholder management and the achievement of various corporate performance goals" [27]. Lastly, it is normative because stakeholders are accepted as groups having an interest in the organization and vice versa, while they are intrinsically motivated [27]. Regarding research in the tourism field, some results support an instrumental perspective, while the normative perspective is neglected [29].

In tourism, the stakeholder theory can be applied to a destination, and many authors have identified different stakeholders contributing to the tourism product, among them many independent businesses [8,22]: "The DMO shall act as a facilitator to achieve the strategic objectives of the destination" [30]. As independent units, these businesses are operated by individual entrepreneurs, none of whom have dominant administrative power at the destination [6,31]. In tourism, however, research has long neglected private tourism businesses' role in destination development and competitiveness [6,32]. The business' fulfillment of all stakeholders' interests results in significant long-term returns from tourism as a whole, thus enabling a destination's sustainable development [33-35]. Thus, for tourism destinations, sustainable leadership and entrepreneurship are anchored in stakeholder-oriented management, rendering cooperation activities crucial for a destination's development, sustainability, and longevity [36]. Destination planning and development [37-39] are key to a tourism destination's long-term development prospects and ensure its competitiveness [40]. As for a tourism destination's development and governance, today's approach follows a relatively more inclusive, bottom-up understanding, in which businesses and local communities are encouraged to provide input into their destinations' direction of development [41,42]. Formal structures, such as DMOs, are expected to facilitate such interaction [43].

According to Starik and Kanashiro [44], the sustainability theory explores the development of sustainability solutions that are "multi-level, systematically integrated (including their inputs, processes, outputs, and feedbacks), and multi-stakeholder-oriented" [44] (p. 17) and definitely applicable to tourism. In community-type destinations, tourism family businesses contribute to and shape the local economy's sustainable development [45]. Hörisch et al. [46] thus argue that stakeholder theory and sustainability share many ideas and, although they are no guarantee, "encourage ... paths leading toward sustainable development" [46] (p. 341) [14]. For sustainable tourism development, all stakeholders must be involved in the process [14,27]. Given that family businesses are the main provider of the tourism product embedded in community type destinations, they also need to be systematically integrated in the development of the vision and strategy of the destination [45,46]. However, trade-offs and conflicts might exist across different stakeholders [26,28]. Hence, it is essential to manage the relationships across stakeholders along their mutual interests as well as interdependencies [46]. The stakeholder and sustainability theories are about how to overcome challenges, conflicts, and trade-offs among stakeholders by addressing responsibilities and aligning interests - this also shows the fit between sustainability and stakeholder theory [28,46]. Thus, the success of these strategies crucially depends on the compliance of all individual stakeholders and their relationships within the destination, and results in creating value in a responsible, sustainable manner as well as synergies across stakeholders [46].

\subsection{Family Firms as Major Tourism Stakeholders}

Family-business research based on stakeholder theory suggests that family firms acquire more operational control and legitimacy or enrich their images as instrumental goals of adapting proactive stakeholder engagement [47,48]. A plethora of different concepts of proactive behaviors has been developed, including, for example, organizational spontaneity [49], personal initiative [50], intrapreneurship [51], contextual performance [52], and proactive behavior [47]. By encouraging 
proactive stakeholder engagement, the family most supports stakeholders who increase family control and firm survival. In a normative stakeholder approach, the family acts through altruism and family values [23].

The tourism sector comprises various specific stakeholder groups, such as hotels, municipalities, event organizations, cable car companies, and DMOs [22]. Thus, tourism affects multiple stakeholders, for instance, the local population and tourism firms and authorities, which in functioning tourism planning have a shared vision for creating the tourism product $[13,53]$. Within the destination, different actors need to be coordinated [54]. For a large number of small- and medium-sized family businesses, a common strategic orientation is especially important [55]. In this setting, DMOs are responsible for coordinating firms' communication and strategic orientation [18]. In addition, tourism research emphasizes social and environmental effects [29]. The interaction effects of strategy and corporate social responsibility (CSR) variables, such as selling intensity, community activities, and improving financial performance, while moderating strategy variables and diversity activities, positively influence environmental performance [29]. Commonly, various segments of tourism are studied, such as tourist carriers, attractions, accommodations, services, tourism marketing, and tourism regulators [56].

Tourism literature argues that research into the influence and coordination of multiple actors participating in strategy development needs to be more detailed [54,57]. The stakeholder theory acknowledges that shareholders influence a firm's performance in the long run, while value creation is not solely reflected in profit maximization [29]. Various studies call for including all stakeholders in the development of a tourism product and its marketing [58]. Therefore, destinations should be seen as multifaceted networks including many firms, local residents, and regional authorities [54].

The reason for applying the stakeholder theory lies in the research suggestion that family firms are proactive in stakeholder engagement [23]. One reason is seen in their protection of socio-emotional endowments [59-61]. Prominently, the concept of socio-emotional wealth (SEW) suggests that family firms focus not only on financial goals, but also incorporate non-financial goals into decision-making to protect the family's well-being [61-63]. This contributes to family firms' different strategic orientation [64]. Family business research thus argues that family firms are more sustainable than non-family firms [65] and that they actively engage in CSR efforts [66]. The main body of literature supports family businesses as more socially responsible and caring about shareholder wealth-this works as a protective mechanism during crises and makes them more successful in the long run [67]. However, as Peake et al. [68] stated, although interest is growing in family firms' socially responsible behavior, readiness for communicating and implementing marketing activities is still limited.

Additionally, tourism literature emphasizes the need to stay competitive and readily adaptable to a changing environment. Therefore, tourism stakeholders need to be aware of future trends and calculate risks and opportunities not only for their businesses, but also for the entire destination [19]. An organization thus sets strategic goals and emphasizes stakeholder relationships to secure sustainability [29]. Thereby, tourism literature proposes a proactive stakeholder approach to stay advantageously competitive [19]. For example, Chen and Dwyer [69] argue that place satisfaction increases residents' proactive participation in regional tourism development. However, family firms decide between proactive and reactive strategies based on their goals and scope of action [70]. Bansal and Roth [71], for instance, showed that firms base their decisions on voluntary sustainability practices according to legitimation, competitiveness, and environmental responsibility. In a similar context, rural tourism family firms are motivated by ecological and social considerations in their sustainability decisions once they have guaranteed economic survival [3].

\section{Method}

This study conducts guided interviews with family firm CEOs $(n=47)$ living in Pillerseetal, Tirol. Usually, the family firm owners participated in the face-to-face interview. This approach offered the opportunity to analyze collected data for implicit, hidden attitudes, thus avoiding social bias in the responses [72]. Data collection occurred from June to October 2017, with all interviews conducted 
in German and lasting from 30 to 50 minutes. Interviews were recorded on an audio voice recorder for transcription, and all audio files were transcribed into a usable text format and analyzed with MaxQDA [73]. The interview guideline was based on the strengths, weaknesses, opportunities, and threats (SWOT) analysis rationale [74,75], as perceived by family firms at the tourism destination. However, for this research, the interviews were analyzed only for perceived risks and did not include deep analysis of opportunities, strengths, or weaknesses.

The major criterion for categorization as a family business was the owners perceiving themselves as such [24]. Initially, $n=50$ interviews were conducted since, at that point, we found data saturation was achieved, that is, no new information or themes were observed [76]. However, in three cases, firm owners declined to perceive the firm as a family business, so the three were excluded from data analysis. Generally, family firms are defined as family members holding over 50\% ownership [25], and usually at least two family members actively participate in daily operations [25]. In 11 cases, family firms reported that other family members did not participate or participated only occasionally. However, they still considered themselves a family business, held the majority of ownership, and thus remained in the sample.

Qualitative data were analyzed using the coding software MaxQDA18. Following Saldaña [77], an in vivo strategy for first-cycle coding was applied to become familiar with the interviewees' language and perspectives. Secondly, holistic coding improved the data overview. Finally, second-cycle coding consisted of eclectic and focused coding to extract the dataset's main characteristics [77]. Two authors first coded the text corpus independently. Then, they merged the codes from the first coding cycle and discussed incoherent codes among team members until all researchers agreed. In cases of opposing viewpoints on a certain code, additional scientists were consulted to discuss them until all scientists agreed. Other studies have applied the same process to reach common understanding of coding in cases of opposing meanings [78]. Finally, all second-order themes were aggregated into abstract themes to create owner-managers' perceptions of risks.

All firms in the study were operating in the tourism industry- 11 were hotels, and 15 were apartments. Eight firms owned agricultural land and operated farms. Other interviewees, for instance, owned pubs or rented rooms, guesthouses, or camping sites. Documented annual revenues in the region were from 2,000 to 2,350,000 Euros.

Table 1 adds an overview of the dataset. Gender was distributed quite equally, with 27 female and 20 male participants. Interviewees' average age was 50 . Their roles were equally managers and business owners, while all were involved in the firms' daily business activities. The firms themselves varied in size, with an average of five employees. The oldest business was founded in 1912, while the average firm was founded in the 1970s. CEOs' ages were usually around 50, with the youngest CEO 28 and the oldest 76 . The number of family members in leadership varied from one to three. Almost all family firms were fully family-owned businesses. The sample included 18 family firms in the first generation, 16 in the second, 10 in the third, and 3 in the fourth or a higher generation.

Table 1. Description of sample: tourism family businesses in the Pillerseetal region.

\begin{tabular}{cccccc}
\hline Variables & N & Minimum & Maximum & Mean & SD \\
\hline Employees & 47 & 0 & 93 & 5.38 & 14.519 \\
Founding year & 47 & 1912 & 2016 & 1978.60 & 25.891 \\
CEO age & 47 & 28 & 76 & 49.64 & 10.218 \\
Family members in leadership & 47 & 1 & 3 & 1.55 & 0.619 \\
Family ownership (\%) & 47 & 90 & 100 & 99.91 & 0.928 \\
Generations & 47 & 1 & 4 & 1.96 & 0.932 \\
First Generation & 18 & & & & \\
Second Generation & 16 & & & & \\
Third Generation & 10 & & & &
\end{tabular}




\section{Results}

As mentioned in the introduction, first, risks perceived by family firms were identified. As major categories, predominant risk areas extracted from the data included climate change, price dumping, hiring qualified labor, and destination development. In the following, the paper discusses how firms perceive these four topics. Others identified will not be discussed further.

While this study revealed no substantial differences in risk perception among generations of family firms or interviewees' ages, future research should explore differences in risk perception and identification among generations. It would be interesting to discover whether family firms distinguished according to CEO tenure or to succession-planning vary in risk perception.

\subsection{Climate Change}

Numerous interviewees identified climate change as a major risk, because of the destination's dependence on winter tourism, such as skiing holidays. For example: "If there is no [snow in] winter anymore, because of climate change ... The only real risk is that the [snow fall during the] winter season is changing drastically. During the last years, this [snow fall] has already been less, however skiing was possible." (Interviewee No. 073). Another interviewee stated: "And of course, these snow-free winters where the winter landscapes are not as fantastic as they used to be in the region, with $\frac{3}{4}$ meters of snow on the rooftops. Altogether, it's just a bit more challenging at the moment" (Interviewee No. 033). Owners perceived themselves as part of the destination when they addressed climate change. While the presence of climate change was identified as a risk, no opportunities were recognized in how to adapt to the changing environment at a firm level. Consequences for the future were addressed without considering a business model adaption: "If it does not snow anymore, then we remain with the summer season, just like in the past. And for the summer season alone, we unfortunately are too 'low priced', so that we cannot keep the business afloat with the summer season only. One would have to do a lot to rise prices" (Interviewee No. 018).

While climate change is perceived as a risk, the interviewees did not intend to take action against the changing business environment, but rather watched its development from a distance: "And what is also a big risk meanwhile is the amount of snow because it determines the start of the winter season. We also depend on how the mountain railway develops concerning artificial snow-making investments. In this regard, Fieberbrunn is already relatively well off." (Interviewee No. 029). Rather than proactively suggesting alternative scenarios for the future, family firms perceived the shutdown of local, low-altitude skiing areas as a great risk, which they observed but considered outside their scope of action:

One risk, of course, is climate change, and that's where the existence of the winter ski operations of the Pillersee mountain railway comes into play. This has also been the subject of discussion at the moment, because if the cable car goes bankrupt or limits its winter operations, because that has already been considered, then of course this may have an effect on the attractiveness of our location. ... The positive thing is that probably, but negotiations are currently under way, the mountain railway has found partners or investors to simply expand snow making and storage ponds once again, and also a new lift system in the ski area. So, the ski area is preparing for the future, for the next 15 years. (Interviewee No. 032)

Thus, ski area investments and expansion were seen as near-future chances to reduce the risk of climate change. However, no other action was considered to combat climate change, thus demonstrating a sometimes conscious neglect of long-term development. Some even brought forward the argument that snow security is higher today than a few years ago due to artificial snow making:

The only risk is the skiing area and the winter. But there was also a meeting, as mentioned by the business association, where climate studies were investigated. There were forecasts 20 years ago that it would no longer be possible to ski at this altitude (but you still can), that 
were predicted 20 years ago. So I do not think it's that dramatic for the next 10-15 years, and you cannot look into the future any further anyway. With artificial snow-making investments, it is even safer today than before and much more predictable than even 20-30 years ago, when artificial snow did not exist. Since the altitude of the skiing resort has always been an issue, today it is not so much anymore. Because, if there is no snow anywhere, then Ischgl or other higher altitude ski areas are just as bad off as we are. Then, it depends on the capacity of the snow making. (Interviewee No. 032)

While ski areas and their infrastructure were given high importance for the future, this was connected not only to climate change: "It would be a risk when the infrastructure facilities such as the skiing area Bergbahn Steinplatte no longer exist. Then, in the winter, everything would be gone; there would be nothing left" (Interviewee No. 080).

One interviewee proposed a soft tourism approach, while referring to the risk of losing winter tourism as an alternative: "The first risk is [having less snow in] the winter with [rising] temperatures. Snow and climate are the primary risks I already see. I see more future for summer tourism, such as soft summer tourism" (Interviewee No. 042). In most other cases, summer tourism was seen as a chance to develop and offset seasonality, rather than an approach to counterbalance decreasing winter tourism. The concept of soft tourism basically encompasses environmental and social compatibility, optimum wealth creation, and even establishing a new culture of traveling [79].

To sum up, climate change was clearly perceived and explicitly mentioned as a major risk for tourism business entrepreneurs in the future. However, interviewees' statements revealed that this stakeholder group did not consider climate change a focus for risk management and demonstrated almost no effort in determining actions to address this risk. Rather, they focused on short- to mid-term symptoms, mainly lack of snow and actions by other stakeholders, for example, the DMO, the ski area, or cable car companies, to deal with these symptoms-mainly in the form of artificial snow. While family firms partially acknowledged that they are involved in discussions of the problem with the $\mathrm{DMO}$, they expected the problem to be solved externally and remained reactive rather than proactive. The mention of switching to soft tourism as a proactive measure can also be seen as a more general strategic undertaking, independent of climate change as a specific problem.

\subsection{Price Dumping}

Throughout the interviews, price dumping at the destination was considered a major risk. Price dumping includes offering one's own product at a price below the average, especially in the off-season. Smaller family firms worried about price pressure from larger hotels expanding their capacities: "I do not work for free; others already do, like the big hotels. I see the offer of a five-day all-inclusive holiday for 250 Euros, and I cannot keep up with this. I cannot do that, I do not do that, I work in vain, I do not like that, it is cheaper to leave" (Interviewee No. 087). This interviewee continued: "When people generally stay away [fewer visitors], then only the big hotels get booked. When they lower their prices, it is something to be scared of; the all-inclusive offers, including huge wellness areas ... chain hotels that are built, not directly in Hochfilzen, but in the neighboring communities, e.g., Fieberbrunn, they are now building another one with 200 beds. They also have to be fully booked during summer. I know at which price level they are fully booked. And you simply cannot compete as a smaller [accommodation provider]" (Interviewee No. 087). Price dumping was therefore perceived as a risk within the stakeholder group. Clearly, the family firm owners identified themselves strongly with the risk and were affected directly. However, they blamed other family firms responsible for the situation.

Within the stakeholder group, price pressure was mentioned among smaller apartments and hotels, as well as from hotels that have to keep up with the increasing competition from other hotels. One interviewee described the pressure to offer better performance for the same price as risky to the industry: 
I see price dumping as a great risk. And vice versa, not that it is too low-priced, but that performance is brutally increased. I think this development is fatal. I know a hotel that has an all-inclusive offer of 30 Euros per night. They work only with intermediaries probably, even privately, but above all, they have 500 or 600 beds, and there with the high number of beds it works, but only there it works. I say, this is lethal for small businesses, because you just cannot maintain the price performance [of chain hotels].

The interviewee continued: "I just think that some have implemented a new wellness area every 5 years and that is deadly when you turn off common sense because that alone does not matter at all. I have worked in a hotel that has had a huge indoor pool, but never ever have guests been inside" (Interviewee No. 049).

While interviewees revealed increased awareness about dumping prices, which degrades the destination's profitability and reputation, none mentioned offering low prices themselves. Surprising in this context is that, quite inconsistently, owners frequently perceived expanding their businesses' capacity as a major future opportunity to deal with this risk. At the same time, exploding bed numbers from larger hotels were perceived as a risk for the destination. One interviewee stated: "The camping sites are getting smaller. So we can fit six to ten guests more by using the same place. That's all done, so I don't have any more investments there" (Interviewee No. 031). Another thread of the argument examined at the destination level, with interviewees suggesting cooperative management of price wars: "The destination just lives again and everyone benefits; a community founded on giving and taking and not only price dumping and competition. When everyone is in tune, nothing will happen" (Interviewee No. 043). Thus, the family firm owners perceived themselves as able to manage the risk when working together.

In sum, quotations here show that competition, especially through low prices and capacity expansion, was perceived as a major risk by many firms. According to the interviewees, mostly smaller firms, especially apartments, have greater difficulty coping with low prices and the tendency to provide more extras. In contrast to climate change, interviewees clearly perceived price risk as the responsibility of CEOs who must set prices and consider investments to stay profitable. However, firms considered their opportunities for action as quite constrained for managing risk on their own and called for collective management within the stakeholder group. Throughout the interviews, the family firm owners did not mention the DMO as able to manage the risk of price dumping, while they saw the connection to destination brand management. One reason is that the Pillerseetal is not perceived as a strong brand compared to other well-known skiing areas, for instance, the high-priced destination Ischgl. Here, interestingly, risk was not externalized but seen as the firms' core responsibility. However, the single firm appeared limited in its scope of action to prevent regional price dumping, and although they mentioned the opportunity for collective actions to rise prices, they remain passive in their risk management.

\subsection{Qualified Labor}

A central topic among the interviewees was the risk of finding qualified staff, which was described an industry-specific risk. One interviewee stated: "Staff shortage is also a risk. If I do not get a cook" (Interview No. 025). One interviewee states: "The risk is that I do not find qualified staff. This can be threatening our existence, when you cannot find any qualified labor" (Interviewee No. 079). Others told stories about staff shortages experienced in other firms: "That they could not find a maid. Staff is a big weakness, a huge weakness, but I believe for everyone. How many had to shut down their hotel because they did not get a cook in the winter? That's bad, very bad. If you have to lock up because you cannot get any staff-it cannot get any worse, I think" (Interviewee No. 006). Owner-managers generalized the search for qualified labor as a structural problem of the tourism industry: "Employees? You no longer get qualified employees! That is a risk" (Interviewee No. 043). One interviewee addressed the image of the tourism industry as an inhibiting factor: "I do not think it [working conditions] is so bad now, because they also have to work on Sundays in hospitals. But, 
it is the bad reputation [of the tourism industry] which is told to them already at high schools. ... Speaking about tourism so negatively at high schools where they tell everyone not to work in the tourism industry" (Interviewee No. 011). While the family firm owners reason staff shortage with tourism's image problems, hard working conditions were rarely mentioned by the interviewees, who perceived staff shortage as an industry risk.

However, some interviewees related to staff shortage as a risk on the firm level, admitting demanding working conditions. One interviewee described difficult working days and hours in reference to the business: "We had a chef who was emaciated; he worked four to five weeks on the row before we managed to hire [a second] chef, so that the chef could have one day off" (Interviewee No. 058). This interviewee also regarded the responsibility of searching for qualified staff early enough before starting the season as a firm's crucial competence. The interviewee owned one of the top-performing family firms at the destination and seemed strategically focused. In contrast to pushing staff shortage toward an industry-specific challenge, this family business owner was reflective about and proactive in his own contribution to keeping qualified staff. During the interview, appreciation of his staff and the fact that the business is also responsible for how it treats its employees to make them stay, emerged: "Of course, human resources management, I must say, is often a bit questionable among companies. I see it as teamwork. Without the employees, we do not succeed. That's why you have to work together and make the best out of it. What I have heard of companies with poor staff management ... that, of course, also gets back on you." The strength of the company was expressed as a way to manage the risk of finding qualified labor by working as a team and paying staff a wage premium of $30-40 \%$ above the average wage:

This is the employee who performs great work in the right position. It may also be the bartender who communicates a bit more open-minded, the head waiter who has what it takes to care well for our guests, the maid who works clean, the chef at the buffet who may make a joke showing Tirolean hospitality. That's all the familiar [atmosphere you can create]. (Interviewee No. 058)

In brief, finding staff is a major risk for firms and one they face during the season. Clearly, firm CEOs were aware of tourism's tough working conditions, including long working hours, few days off during the season, and working on weekends and late at night. However, family businesses addressed this risk variously. Some owner-managers did not discuss their responsibility for improving working conditions. Rather, owners externalized staff shortage as a problem and perceived it as the tourism industry's structural risk. No suggestions emerged on how to deal with it, and DMOs were not mentioned in this context. Others indicated the importance of dealing with this risk themselves, i.e., through expressing the importance of good human resource management. In this case, family businesses perceived the risk of finding qualified labor at the industry level, but as contributing to risk management at the firm level.

\subsection{Destination Development and Marketing}

Owner-managers perceived the risk of stagnating destination development. Even though family firms did not directly address the DMO as a stakeholder, they did show a sense of community and wished destination development to benefit all stakeholders:

When everyone is included, then nothing can happen. You will always have a situation where you will not be able to avoid that there is a black sheep [but this will not harm the destination, if everyone works together]. If locals appreciate their home region more again and will also consume more, go out to eat, this is just as important. (Interviewee No. 043)

The risk of stagnating destination development was also perceived as a chance for personal benefit: "I see opportunities for others and for myself in emphasizing the region. It is already strong but could be increased even more in promoting regional products and their purchase and emphasizing the regional 
environment and the conscious living; simply promoting the regional economy more" (Interviewee No. 043). Thus, rather than delegating risk management to the DMO level, owner-managers perceived themselves as responsible for managing destination development.

One interviewee told the story of Leogang's development to overcome risk of stagnating destination development. Today, Leogang outperforms Pillerseetal, but it was initially less developed. However, one interviewee regarded family firm owners' action of forming a small, innovative community as responsible for its success, in contrast to the DMO being responsible for destination development: "The people of Leogang did not manage it, because the DMO was doing great, but because they sat together and discussed what they can offer with regards to new products and the companies have just reacted a bit more quickly and have invested more. That's how I perceived it" (Interview No. 058).

Furthermore, interviewees addressed lack of marketing skills as a risk: "Advertising. Marketing is certainly our weakness" (Interviewee No. 078). However, they argued that small and medium structured firms struggle to have the financial resources to implement marketing efforts: "Then maybe it's the advertisement; that I do not put enough effort in it. However, that's all a matter of money" (Interviewee No. 031). Or: "And saying I hire someone just for the marketing activities is almost [too much] to bear for such a small business as mine is" (Interviewee No. 032). Another interviewee stated: "If we had more rooms, then it would be easier for us, and, of course, you can do more marketing" (Interviewee No. 044). Throughout, the interviewees did not connect lack of marketing to the DMO's responsibilities. Only one time was Pillerseetal's lack of reputation addressed independently of individual marketing performance: "The strength is the sunny and quiet location; the weakness is the unknown valley. That is, the unknown location and the much weaker demand for offers in our valley, due to being unknown" (Interviewee No. 058). When asked about the lack of marketing, the interviewees answered from a person-centered viewpoint, not mentioning the DMO's responsibility to engage in marketing activities.

In short, family firms identified risks of stagnating destination development and the region's lack of brand recognition. While the DMO's core competences should be building a destination brand and its reputation and supporting its marketing, family firms did not perceive the DMO as responsible for marketing or destination development. They did not blame the DMO for their perceived risk of Pillerseetal's weak brand recognition, but rather saw destination development as within their scope of action. Furthermore, they acknowledged their weaknesses in marketing as risky and focused on their community as an important factor in managing the lack of marketing. However, owners seemed to see individual and joint opportunities for proactive action to improve the destination's current situation. Interestingly, this region's actively participating DMO was perceived more positively than average [80]. Maybe perceived opportunities for proactiveness among stakeholders explain this positive attitude.

\section{Discussion and Conclusions}

In the literature, stakeholders' proactive behavior at a tourism destination is considered as contributing significantly to success in sustainable destination management [69]. As stated in the literature review, several approaches of proactivity exist [47,49-52]. In this empirical investigation of Pillerseetal, both proactive and reactive elements were found, possibly explained by the stakeholder theory framework. Stakeholders externalize some risks. Consequently, they see limited scope for their own actions and are only reactive, as in this example with climate change, price dumping, and staff shortage. In contrast, they tend to internalize other risks, like brand development and marketing, along with "bringing the village back to life" and, consequently, make more proactive statements. This also reveals that family owners follow a normative stakeholder approach due to altruism and family values [23].

Asking family owners which future risks they perceive aided understanding of this special stakeholder group and how they are linked to destination development. Regarding the identification of climate change as a risk, family business owners rely on investments for existing ski areas. In doing so, they do not recognize opportunities to change their business models and develop new competitive 
advantages. This contradicts previous findings [27]. Instead, they focus on other stakeholders' risk management to guarantee a continuing winter tourism season. Thus, managing the risk of climate change is not perceived as lying within a family firm's scope of action but is externalized to the DMO.

At the destination, price dumping is perceived as a major risk hindering its development. However, especially the stakeholder group of smaller accommodation providers attacked larger hotels' dumping strategies, implying differences in interest within accommodation providers' stakeholder group. Paradoxically, owners also considered increasing their business capacity as a future opportunity to deal with price dumping. During interviews, family firm owners also mentioned the community and appeared socially-oriented. This is congruent with the SEW theory, which sees family firms as embedded in their social environment and showing stronger responsibility toward society, and particularly toward the local community $[63,66]$. However, they did not connect risk of stagnating destination development with overcapacity in potentially expanding their own businesses. This contradicts d'Angella and Go [18], who found the relationship between single tourism providers and the DMO crucial for long-run competitiveness.

Previous research showed that the hospitality industry records higher levels of labor shortage and turnover than other sectors $[81,82]$. One major reason for this might have roots in the bad employer image of the hospitality industry, which must often rely on unskilled labor to meet the shortage [83]. However, rather than taking responsibility as employers, risk is externalized as a tourism industry structural issue. This is particularly interesting, since family businesses are usually characterized by particular sustainability efforts, stability, and social working conditions [84]. Finally, regional development's stagnation and local restaurants' shutdowns were perceived as major destination risks. Surprisingly, family firms do not externalize these risks for DMO solution. Rather, family firms feel responsible for their region's development. This can be traced to the SEW construct referring to family firms' non-economic goals and social responsibility toward the municipality and, in this case, the tourism destination [23,61-63]. Equally, lack of marketing skills is considered a firm-related risk not externalized to the DMO. In this case, a possible explanation is that the DMO was merged. Historically, five independent DMOs were responsible for the areas of Fieberbrunn, Hochfilzen, St. Jakob in Haus, St. Ulrich am Pillersee, and Waidring [80]. This runs contrary to previous studies, which called for including all stakeholders in development of a tourism product and its marketing and for certifying the DMO's major marketing role [58].

Before concluding, the study's limitations will be discussed. First, the qualitative data examined family firms exclusively, making comparison to non-family firms impossible. Secondly, due to the small- and medium-sized structure of family businesses at the destination, drawing conclusions about larger firms seems inappropriate. Additionally, the generalizability of data to other destinations needs yet to be proven, given that owners at a single destination were interviewed. Furthermore, the results' subjectivity or the researcher's over-involvement in the interviewing situations might also be regarded as limitations, as with any qualitative data, because owners were very talkative and sometimes strayed from the given topic. For future research, a multiple case study approach would improve external validity. While this study revealed no substantial differences in risk perception among different generations of family firms or ages of interviewees, future research should explore risk perception and identification along the generations. Therefore, it would be interesting to investigate whether family firms that distinguish according to $\mathrm{CEO}$ tenure or succession-planning vary in risk perception.

This study offers some practical implications for improving sustainable tourism development; these are differentiated according to unit of analysis-firm level versus destination level.

At the firm level, family businesses should engage in employer branding strategies to resolve labor shortages, regarded as a major risk. To improve existing employees' quality, training programs could be offered, and work-life balance, e.g., a five-day-week, should be considered. Regarding price dumping, specialized offers for specific target groups provide potential for differentiation strategies.

At the destination level, since family firm owners mention price dumping as a major risk, a strong brand can improve the destination-wide price level. A practical implication relates to brand 
building, which is the DMO's core competence and responsibility. Branding results in enhancing the entire destination's reputation. Moreover, since small family firms in rural tourism are captive to their operations and thus can devote little time to strategic planning, stakeholder engagement between the $\mathrm{DMO}$ and family firms needs to be strengthened in the long run. Another practical implication relates to climate change, clearly perceived as a major risk for business entrepreneurs. Given that family firm owners externalized this risk, the tourism destination's other stakeholders, for instance, the DMO, the ski, and cable car companies, might need to take action. More generally, owner-managers also need to develop common strategies in cooperation with the DMO, because single family firms do not have the capability and capacity to develop the tourism destination sustainably. Thus, collaboration among stakeholders, especially with the local DMO and other family firms, is highly recommended [85].

Finally, this study provides insight into the risk perception of family businesses operating in the tourism sector. For sustainable tourism development, this is essential since risk must be managed to secure the destination's long-term success. From a stakeholder perspective, the Pillerseetal destination revealed that owners externalize some, but not other, risks for other stakeholders' management. These points indicate room for improving Pillerseetal's performance, especially by the DMO tapping into family firms' apparent willingness to participate in the community. On the other hand, the externalization of mid-term action for addressing effects of climate change might be considered a sign of the DMO's successful work. The DMO could probably leverage its stakeholders' satisfaction to address the strategically important features of labor shortage and price dumping. However, these are more difficult risks to address because various stakeholders' interests diverge.

These results point to a more complex relationship than the literature previously assumed in sharing responsibilities and activity between the DMO and its stakeholders. Stakeholders address various risks very differently because they perceive those risks differently. The crucial dimensions seem to be the time horizon of risks, the range of possible actions, whether needed actions are considered the entrepreneurs' responsibility, and whether different stakeholders' interests diverge. If interests align, as in the case of climate change, and actions are not considered core business activities, then responsibility is happily assigned to the DMO. In diverging interests, as in price dumping and labor shortage, this is not true, but firms remain reactive, nevertheless. Although typically the DMO's responsibility, interestingly, proactiveness was suggested in marketing and destination development. More research is needed to discover which general lessons can be learned for stakeholder engagement in destination development. A quantitative approach would definitely be of benefit in testing some of our findings and also result in more rigorous data, which might help derive further implications on both the family business and the destination levels.

Author Contributions: Conceptualization, G.G. and A.Z.; methodology, G.G.; software, G.G.; validation, G.G. and A.Z.; formal analysis, G.G. and A.Z.; investigation, G.G..; resources, G.G. and A.Z; data curation, G.G.; writing-original draft preparation, G.G.; writing-review and editing, A.Z.; visualization, G.G.; supervision, A.Z.; project administration, A.Z; funding acquisition, A.Z.

Funding: This research was funded by the Tourism Research Center of the Tyrolean Government.

Acknowledgments: Open Access Funding by the MCI Management Center Innsbruck.

Conflicts of Interest: The authors declare no conflict of interest. The funders had no role in the design of the study; in the collection, analyses, or interpretation of data; in the writing of the manuscript, or in the decision to publish the results.

\section{References}

1. Yoe, C. Principles of Risk Analysis: Decision Making Under Uncertainty, 2nd ed.; CRC Press: Boca Raton, FL, USA, 2019; ISBN 0429021127.

2. Statistik Austria. Tourismus in Österreich-Ergebnisse der Beherberungsstatistik. Available online: https://www.statistik.at/web_de/statistiken/wirtschaft/tourismus/beherbergung/ankuenfte_naechtigungen/ index.html (accessed on 14 October 2018). 
3. Kallmuenzer, A.; Nikolakis, W.; Peters, M.; Zanon, J. Trade-offs between dimensions of sustainability: Exploratory evidence from family firms in rural tourism regions. J. Sustain. Tour. 2018, 26, 1204-1221. [CrossRef]

4. Amt der Tiroler Landesregierung. Landesstatistik Tirol-Bestandserhebung der Betriebe und Betten. Available online: https://www.tirol.gv.at/statistik-budget/statistik/tourismus/ (accessed on 28 January 2019).

5. Flagestad, A.; Hope, C.A. Strategic success in winter sports destinations. A sustainable value creation perspective. Tour. Manag. 2001, 22, 445-461. [CrossRef]

6. Zehrer, A.; Hallmann, K. A stakeholder perspective on policy indicators of destination competitiveness. J. Destin. Mark. Manag. 2015, 4, 120-126. [CrossRef]

7. Carlsen, J.; Getz, D.; Ali-Knight, J. The environmental attitudes and practices of family businesses in the rural tourism and hospitality sectors. J. Sustain. Tour. 2001, 9, 281-297. [CrossRef]

8. Zehrer, A.; Raich, F.; Siller, H.; Tschiderer, F. Leadership networks in destinations. Tour. Rev. 2014, 69, 59-73. [CrossRef]

9. Tourismusverbände Tirol. Leitbranche Tourismus. Available online: https://www.tirolwerbung.at/tirolertourismus/ (accessed on 28 January 2019).

10. Tirol Werbung. Die Geschichte des Tiroler Tourismus. Available online: https://www.tirolwerbung.at/tirolertourismus/geschichte-tiroler-tourismus/ (accessed on 28 August 2019).

11. Bergbahnen Fieberbrunn. Freeride World Tour Fieberbrunn. Available online: https://www.fieberbrunn. com/de/winter/freeride/freeride-world-tour (accessed on 28 August 2019).

12. Pillerseetal, T.V.B. Kitzbühler Alpen-Pillerseetal. Available online: https://www.kitzbueheler-alpen.com/de/ pillerseetal/urlaub-skifahren-langlaufen.html (accessed on 29 January 2019).

13. Yuksel, F.; Bramwell, B.; Yuksel, A. Stakeholder interviews and tourism planning at Pamukkale, Turkey. Tour. Manag. 1999, 20, 351-360. [CrossRef]

14. Byrd, E.T. Stakeholders in sustainable tourism development and their roles: Applying stakeholder theory to sustainable tourism development. Tour. Rev. 2007, 62, 6-13. [CrossRef]

15. Shortridge, J.; Aven, T.; Guikema, S. Risk assessment under deep uncertainty: A methodological comparison. Reliab. Eng. Syst. Saf. 2017, 159, 12-23. [CrossRef]

16. McShane, M. Enterprise risk management: History and a design science proposal. J. Risk Financ. 2018, 19, 137-153. [CrossRef]

17. Pike, S.; Page, S.J. Destination Marketing organizations and destination marketing: A narrative analysis of the literature. Tour. Manag. 2014, 41, 202-227. [CrossRef]

18. D'Angella, F.; Go, F.M. Tale of two cities' collaborative tourism marketing: Towards a theory of destination stakeholder assessment. Tour. Manag. 2009, 30, 429-440. [CrossRef]

19. Dwyer, L.; Edwards, D.; Mistilis, N.; Roman, C.; Scott, N. Destination and enterprise management for a tourism future. Tour. Manag. 2009, 30, 63-74. [CrossRef]

20. Freeman, R.E.; McVea, J. A stakeholder approach to strategic management. Blackwell Handb. Strateg. Manag. 2001, 189-207. Available online: http://dx.doi.org/10.2139/ssrn.263511 (accessed on 4 December 2019).

21. Bornhorst, T.; Brent Ritchie, J.R.; Sheehan, L. Determinants of tourism success for DMOs \& destinations: An empirical examination of stakeholders' perspectives. Tour. Manag. 2010, 31, 572-589. [CrossRef]

22. Sheehan, L.; Ritchie, J.R.; Hudson, S. The Destination Promotion Triad: Understanding Asymmetric Stakeholder Interdependencies Among the City, Hotels, and DMO. J. Travel Res. 2007, 46, 64-74. [CrossRef]

23. Cennamo, C.; Berrone, P.; Cruz, C.; Gomez-Mejia, L.R. Socioemotional wealth and proactive stakeholder engagement: Why family-controlled firms care more about their stakeholders. Entrep. Theory Pract. 2012, 36, 1153-1173. [CrossRef]

24. Sieger, P.; Zellweger, T.; Aquino, K. Turning agents into psychological principals: Aligning interests of non-owners through psychological ownership. J. Manag. Stud. 2013, 50, 361-388. [CrossRef]

25. Chua, J.H.; Chrisman, J.; Sharma, P. Defining the Family Business by Behavior. Ent. Theory Pract. 1999, 23, 19-39. [CrossRef]

26. Freeman, R.E. Strategic Management: A Stakeholder Approach; Pitman: Boston, MA, USA, 1984; ISBN 0521151740.

27. Donaldson, T.; Preston, L.E. The stakeholder theory of the corporation: Concepts, evidence, and implications. Acad. Manag. Rev. 1995, 20, 65-91. [CrossRef] 
28. Freeman, R.E.; Harrison, J.S.; Wicks, A.C.; Parmar, B.L.; de Colle, S. Stakeholder Theory: The State of the Art; Cambridge University Press: Cambrige, UK, 2010; ISBN 1139484117.

29. Theodoulidis, B.; Diaz, D.; Crotto, F.; Rancati, E. Exploring corporate social responsibility and financial performance through stakeholder theory in the tourism industries. Tour. Manag. 2017, 62, 173-188. [CrossRef]

30. Collins, C.; Buhalis, D. Destination management systems utilisation in England. In Information and Communication Technologies in Tourism. 2003. Available online: https://www.researchgate.net/publication/ 228948690_Destination_Management_Systems_Utilisation_in_England (accessed on 4 December 2019).

31. Eurostat. Smes in Europe: Competitiveness, Innovation and the Knowledge-Driven Society; Data 1996-2001; Theme 4: Industry; Trade and Services; European Communities: Brussels, Belgium; Luxembourg, 2002.

32. Komppula, R. The role of individual entrepreneurs in the development of competitiveness for a rural tourism destination-A case study. Tour. Manag. 2014, 40, 361-371. [CrossRef]

33. Sautter, E.T.; Leisen, B. Managing stakeholders a tourism planning model. Ann. Tour. Res. 1999, 26, 312-328. [CrossRef]

34. Formica, S.; Kothari, T.H. Strategic destination planning: Analyzing the future of tourism. J. Travel Res. 2008, 46, 355-367. [CrossRef]

35. Wang, Y.; Xiang, Z. Toward a theoretical framework of collaborative destination marketing. J. Travel Res. 2007, 46, 75-85. [CrossRef]

36. Beritelli, P. Cooperation among prominent actors in a tourist destination. Ann. Tour. Res. 2011, 38, 607-629. [CrossRef]

37. Hudson, S.; Ritchie, B.; Timur, S. Measuring destination competitiveness: An empirical study of Canadian ski resorts. Tour. Hosp. Plan. Dev. 2004, 1, 79-94. [CrossRef]

38. Blain, C.; Levy, S.E.; Ritchie, B., Jr. Destination branding: Insights and practices from destination management organizations. J. Travel Res. 2005, 43, 328-338. [CrossRef]

39. Gomezelj, D.O.; Mihalič, T. Destination competitiveness-Applying different models, the case of Slovenia. Tour. Manag. 2008, 29, 294-307. [CrossRef]

40. Mariani, M.M.; Buhalis, D.; Longhi, C.; Vitouladiti, O. Managing change in tourism destinations: Key issues and current trends. J. Destin. Mark. Manag. 2014, 2, 269-272. [CrossRef]

41. Hristov, D.; Zehrer, A. The destination paradigm continuum revisited. DMOs serving as leadership networks. Tour. Rev. 2015, 70, 116-131. [CrossRef]

42. Vernon, J.; Essex, S.; Pinder, D.; Curry, K. Collaborative policymaking: Local sustainable projects. Ann. Tour. Res. 2005, 32, 325-345. [CrossRef]

43. Morgan, N. Time for 'mindful' destination management and marketing. J. Destin. Mark. Manag. 2012, 1, 8-9. [CrossRef]

44. Starik, M.; Kanashiro, P. Toward a theory of sustainability management: Uncovering and integrating the nearly obvious. Organ. Environ. 2013, 26, 7-30. [CrossRef]

45. Schaltegger, S.; Wagner, M. Sustainable entrepreneurship and sustainability innovation: Categories and interactions. Bus. Strategy Environ. 2011, 20, 222-237. [CrossRef]

46. Hörisch, J.; Freeman, R.E.; Schaltegger, S. Applying stakeholder theory in sustainability management: Links, similarities, dissimilarities, and a conceptual framework. Organ. Environ. 2014, 27, 328-346. [CrossRef]

47. Crant, J.M. Proactive behavior in organizations. J. Manag. 2000, 26, 435-462. [CrossRef]

48. Katz, D. The motivational basis of organizational behavior. Behav. Sci. 1964, 9, 131-146. [CrossRef]

49. George, J.M.; Brief, A.P. Feeling good-doing good: A conceptual analysis of the mood at work-organizational spontaneity relationship. Psychol. Bull. 1992, 112, 310. [CrossRef]

50. Frese, M.; Kring, W.; Soose, A.; Zempel, J. Personal initiative at work: Differences between East and West Germany. Acad. Manag. J. 1996, 39, 37-63.

51. Hisrich, R.D. Entrepreneurship/intrapreneurship. Am. Psychol. 1990, 45, 209. [CrossRef]

52. Borman, W.C.; Motowidlo, S.J. Task performance and contextual performance: The meaning for personnel selection research. Hum. Perform. 1997, 10, 99-109. [CrossRef]

53. Ritchie, B. Crafting a destination vision: Putting the concept of resident responsive tourism into practice. Tour. Manag. 1993, 14, 379-389. [CrossRef]

54. Haugland, S.A.; Ness, H.; Grønseth, B.-O.; Aarstad, J. Development of tourism destinations: An integrated multilevel perspective. Ann. Tour. Res. 2011, 38, 268-290. [CrossRef] 
55. Peters, M. Wachstum und Internationalisierung. In Überlebenschancen für touristische Klein-und Mittelbetriebe; Linde: Munich, Germany, 2001; ISBN 3-7073-0256-3.

56. Leiper, N. The framework of tourism: Towards a definition of tourism, tourist, and the tourist industry. Ann. Tour. Res. 1979, 6, 390-407. [CrossRef]

57. Ness, H.; Fuglsang, L.; Eide, D. Editorial: Networks, dynamics, and innovation in the tourism industry. Scand. J. Hosp. Tour. 2018, 18, 225-233. [CrossRef]

58. Buhalis, D. Marketing the competitive destination of the future. Tour. Manag. 2000, 21, 97-116. [CrossRef]

59. Gómez-Mejía, L.R.; Cruz, C.; Berrone, P.; Castro, J.D. The bind that ties: Socioemotional wealth preservation in family firms. Acad. Manag. Ann. 2011, 5, 653-707. [CrossRef]

60. Hernández-Perlines, F.; Moreno-García, J.; Yáñez-Araque, B. The influence of socioemotional wealth in the entrepreneurial orientation of family businesses. Int. Entrep. Manag. J. 2019, 15, 523-544. [CrossRef]

61. Berrone, P.; Cruz, C.; Gomez-Mejia, L.R. Socioemotional wealth in family firms. theoretical dimensions, assessment approaches, and agenda for future research. Fam. Bus. Rev. 2012, 25, 258-279. [CrossRef]

62. Gomez-Mejia, L.R.; Neacsu, I.; Martin, G. CEO risk-taking and socioemotional wealth: The behavioral agency model, family control, and CEO option wealth. J. Manag. 2017, 45, 1713-1738. [CrossRef]

63. Gómez-Mejía, L.R.; Haynes, K.T.; Núñez-Nickel, M.; Jacobson, K.J.L.; Moyano-Fuentes, J. Socioemotional wealth and business risks in family-controlled firms: Evidence from Spanish olive oil mills. Adm. Sci. $Q$. 2007, 52, 106-137. [CrossRef]

64. Berrone, P.; Cruz, C.; Gomez-Mejia, L.R.; Larraza-Kintana, M. Socioemotional wealth and corporate responses to institutional pressures: Do family-controlled firms pollute less? Adm. Sci. Q. 2010, 55, 82-113. [CrossRef]

65. Le Breton-Miller, I.; Miller, D. Family firms and practices of sustainability: A contingency view. J. Fam. Bus. Strategy 2016, 7, 26-33. [CrossRef]

66. Dyer, W.G.; Whetten, D.A. Family firms and social responsibility: Preliminary evidence from the S\&P 500. Entrep. Theory Pract. 2006, 30, 785-802.

67. Godfrey, P.C. The relationship between corporate philanthropy and shareholder wealth: A risk management perspective. Acad. Manag. Rev. 2005, 30, 777-798. [CrossRef]

68. Peake, W.O.; Cooper, D.; Fitzgerald, M.A.; Muske, G. Family business participation in community social responsibility: The moderating effect of gender. J. Bus. Ethics 2017, 142, 325-343. [CrossRef]

69. Chen, N.; Dwyer, L. Residents' place satisfaction and place attachment on destination brand-building behaviors: Conceptual and empirical differentiation. J. Travel Res. 2018, 57, 1026-1041. [CrossRef]

70. Spiess, T.; Zehrer, A. Employees' change-oriented and proactive behaviors in small-and medium-sized family businesses. In Entrepreneurship and Family Business Vitality; Saiz-Alvarez, J.M., Leitão, J., Palma-Ruiz, J.M., Eds.; Springer: Heidelberg, Germany, 2020; pp. 49-64. ISBN 978-3-030-15526-1.

71. Bansal, P.; Roth, K. Why companies go green: A model of ecological responsiveness. Acad. Manag. J. 2000, 43, 717-736.

72. Jo, M.-S. Controlling social-desirability bias via method factors of direct and indirect questioning in structural equation models. Psychol. Mark. 2000, 17, 137-148. [CrossRef]

73. VERBI Software. MAXQDA 2018; Berlin, Germany, 2018. Available online: https://www.maxqda.com/justreleased-maxqda-2018 (accessed on 4 December 2019).

74. Helms, M.M.; Nixon, J. Exploring SWOT analysis—Where are we now? J. Strategy Manag. 2010, 3, $215-251$. [CrossRef]

75. Gürel, E.; Tat, M. SWOT Analysis. A Theoretical Review. J. Int. Soc. Res. 2017, 10, 994-1006. [CrossRef]

76. Guest, G.; Bunce, A.; Johnson, L. How many interviews are enough? An experiment with data saturation and variability. Field Methods 2006, 18, 59-82. [CrossRef]

77. Saldaña, J. The Coding Manual for Qualitative Researchers; SAGE Publications: Thousand Oaks, CA, USA, 2012; ISBN 978-1-44624-736-5.

78. Miles, M.B.; Huberman, A.M.; Saldaña, J. Qualitative Data Analysis. A Methods Sourcebook, 3rd ed.; Sage: Los Angeles, CA, USA; London, UK; New Delhi, India; Singapore; Washington, DC, USA, 2014; ISBN 9781452257877.

79. Lusby, C. Hard and soft tourism. In The SAGE International Encycolpedia of Travel and Tourism; Sage: Los Angeles, CA, USA; London, UK; New Delhi, India; Singapore; Washington, DC, USA, 2017. 
80. Glowka, G.; Zehrer, A. Die gesellschaftliche verantwortung von familienunternehmen-Analyse der Interaktionsebene zwischen beherbergung und DMO. In Tourismus und Gesellschaft. Kontakte-Konflikte-Konzepte; Reif, J., Eisenstein, B., Eds.; Erich Schmidt Verlag: Berlin, Germany, 2018; ISBN 978-3-503-18850-5.

81. Kim, N. Employee turnover intention among newcomers in travel industry. Int. J. Tour. Res. 2014, 16, 56-64. [CrossRef]

82. Ferreira, A.I.; Martinez, L.F.; Lamelas, J.P.; Rodrigues, R.I. Mediation of job embeddedness and satisfaction in the relationship between task characteristics and turnover: A multilevel study in Portuguese hotels. Int J. Contemp Hosp. Mngt. 2017, 29, 248-267. [CrossRef]

83. Lacher, R.G.; Oh, C.-O. Is tourism a low-income industry? Evidence from three coastal regions. J. Travel Res. 2012, 51, 464-472. [CrossRef]

84. Krappe, A.; Goutas, L.; von Schlippe, A. The "family business brand": An enquiry into the construction of the image of family businesses. J. Fam. Bus. Manag. 2011, 1, 37-46. [CrossRef]

85. Pechlaner, H.; Beritelli, P.; Pichler, S.; Peters, M.; Scott, N.R. Contemporary Destination Governance: A Case Study Approach; Emerald Group Publishing: Bradford, UK, 2015; ISBN 1783501138.

(C) 2019 by the authors. Licensee MDPI, Basel, Switzerland. This article is an open access article distributed under the terms and conditions of the Creative Commons Attribution (CC BY) license (http://creativecommons.org/licenses/by/4.0/). 